\title{
Interfaces
}

INTERFACES Image Texte Language

$46 \mid 2021$

Jeux de Formats (2)

\section{Challenging the Selfie: Perfect Skin by Chatonsky}

\section{Claire Larsonneur}

\section{(2) OpenEdition}

\section{Journals}

\section{Electronic version}

URL: https://journals.openedition.org/interfaces/4208

DOI: 10.4000/interfaces.4208

ISSN: 2647-6754

\section{Publisher:}

Université de Bourgogne, Université de Paris, College of the Holy Cross

\section{Electronic reference}

Claire Larsonneur, "Challenging the Selfie: Perfect Skin by Chatonsky", Interfaces [Online], 46 | 2021 Online since 15 December 2021, connection on 16 June 2022. URL: http://journals.openedition.org/ interfaces/4208; DOI: https://doi.org/10.4000/interfaces.4208

This text was automatically generated on 16 June 2022.

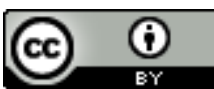

Les contenus de la revue Interfaces sont mis à disposition selon les termes de la Licence Creative Commons Attribution 4.0 International. 


\title{
Challenging the Selfie: Perfect Skin by Chatonsky
}

\author{
Claire Larsonneur
}

1 The word "selfie", which appeared in the early 2000s, made the headlines when it was labelled 'word of the year' in 2013 by Oxford dictionaries, and it entered the French dictionary Le Petit Robert in 2016. As Tifentale argues, selfies are "a hybrid phenomenon that merges the aesthetics of the photographic self-portraiture with the social function of online interpersonal communication" (76). These self-portraits, usually taken on smartphones as snapshots and usually carefully staged, are meant to be shared and repurposed: the same image stored in a hard drive and never posted online would not be a selfie. Selfies, as cultural phenomena, conflate three very distinct types of activity and representation: they pose as the latest avatars of a long tradition of self-portraits; they rely on a set of technologies (digital photography, tagging, editing, posting) embedded in smartphones; they constitute a key component of social media practices where they are massively posted and shared. Art and technology and mass consumption, all in one. In the series Perfect Skin (2007-2020), the French Canadian artist Gregory Chatonsky repurposed the massive dataset of selfies posted by a global celebrity, Kim Kardashian, through a specific generative algorithm to create disturbing decompositions of her figure. This artistic gesture combines two provocations in one: by relying on a machine to produce new images, he undermines the collective representation of the artist as an author; by repurposing images from a disreputable genre, criticized for its narcissism, voyeurism and vacuity, into a form of conceptual art, he blurs the distinction between art and mass media.

2 Chatonsky provides several philosophical and artistic references as the general framework of his project, with a special emphasis on the notion of self-design he took up from Boris Groys. In Going Public, Boris Groys argues that:

It could even be said that self-design is a practice that unites artist and audience alike in the most radical way: though not everyone produces artworks, everyone is an artwork. At the same time, everyone is expected to be his or her own author. Now, every kind of design - including self-design - is primarily regarded by the spectator not as a way to reveal things, but as a way to hide them. (np)) 
Indeed, selfies reshuffle distinctions between intimacy and exposure. Contrary to family photographs, meant to be kept and viewed within small social circles, and contrary to portraits of the rich and famous, whose public display was a measure of their social status, the imperative of staging one's presence online led to the phenomenon of serial selfie posting, which in turn fed the growing amount of online personal data available for tagging, sharing and monitoring. The call for proposal of the 2019 Figurations conference formulated the hypothesis that "data increasingly characterizes what it means to be a person in the present. [Yet] not every person predicated by data is predicted the same. The intersection between data and person isn't fixed: it has to be figured." ${ }^{1}$ Kim Kardashian's career and fortune depend upon the massive posting of selfies: the scale of posting and the various businesses (makeup, underwear brands) they fuel means those snapshots act as valuable data for selfbranding. By reframing those snapshots through his custom-made AI algorithm, by using them as datasets rather than representation, Chatonsky precisely intervenes on the interaction between data and person. When generating alternative images, Perfect Skin enacts another predication of Kardashian's data. Using algorithms also enables Chatonsky to shift the cognitive and artistic reception of the selfie: from the visual arts to mathematics, from representation to data, from creative control to chance, from recognition to perceptual aporia, from social media to the gallery. Being both an artist and an essayist, his work articulates artistic proposals to recent concepts and a critique of our media-obsessed societies. How does Perfect Skin echo these theoretical explorations and how does it repurpose the art of the portrait, the archetypical mimetic endeavour, through a machine-driven manipulation of data? To what extent does Chatonsky take up the codes of the selfie or does he subvert them? Can repurposing social media material stand as genuine creative work and to what degree can Chatonsky claim to be the author? We will first explore how Chatonsky harnessed digital technology, using variables and discretization, to reformat Kardashian's selfies before focusing on the type of disfiguration he produces. A comparison with Francis Bacon's portraits will shed light onto the strategies of legitimation at work, leading to an examination of the politics of self at play in our societies.

\section{Variations on data}

4 For the Perfect Skin project, Chatonsky gathered a dataset of pictures posted by Kim Kardashian on Tumblr and Instagram on which he ran a dedicated algorithm to generate a series of recomposed images of the celebrity. The images are accompanied by captions and hashtags that function as hyperlinks within his website, such as "3D, endless, face, Instagram, landscape, life, photogrammetry, portrait, realtime, selfie, skin." 
Figure 1. A computer-generated mash-up of Kim Kardashian's selfies, from the 2015 series.

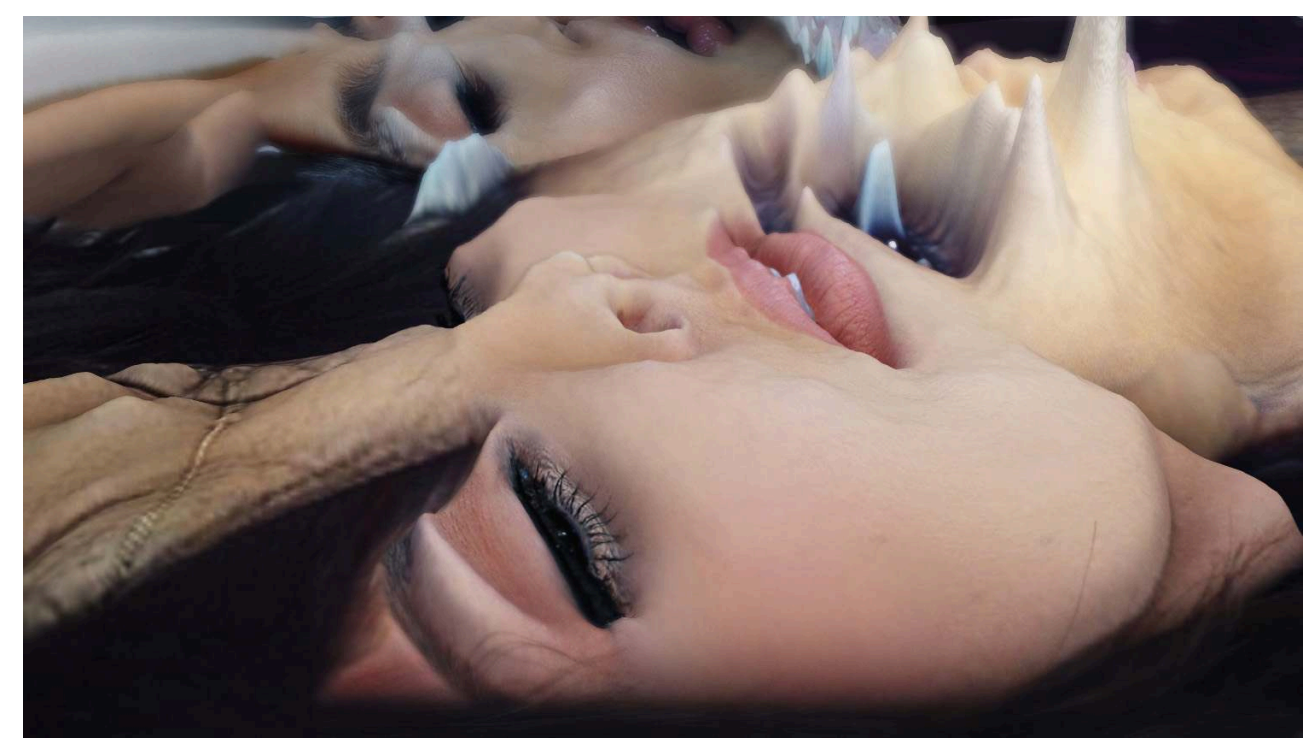

5 The features of Kim Kardashian remain recognisable but the mash-up of hundreds of selfies produces a disturbing and grotesque picture. Each image is made up of multiple takes on Kim, the process echoing the selfie frenzy displayed on her social media accounts. The computer-generated re-composition of the relations between the parts and the whole is potentially infinite and lends itself to a serial display. One of the distinctive features of Perfect Skin is indeed its serial form and the variations in format it enables. The series has been running from 2007 to 2020, with eleven instalments. For its 2007 prototype, a 3D mapping technology normally used in the video gaming industry was applied to unfold Gregory's face, laying it flat like 'flayed skin', in his own words. ${ }^{2}$ This first attempt at digital disfiguration evokes a modern times Marsyas, whose artistic achievement came at a personal cost. 
Figure 2. 3D remapping of Chatonsky's face, 2007.

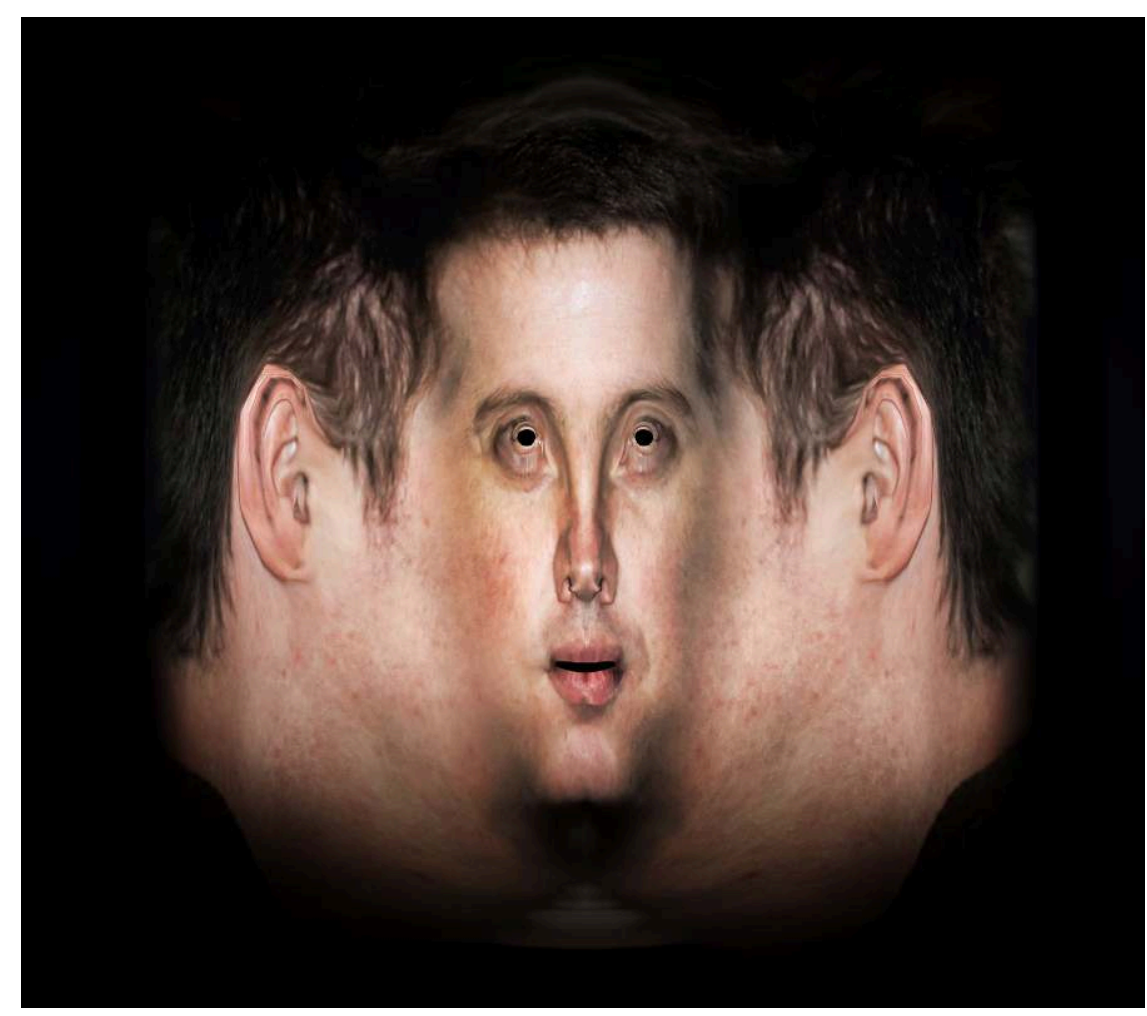

(c) Gregory Chatonsky.

6 But when Chatonsky started using Kim's photographs in 2015 for Perfect Skin II, his perspective changed: he appropriated and criticized Kardashian's attempt to embody a canon of female beauty and to establish herself as an artist (via the publication of a collection of her selfies by the art publisher Rizzoli for instance). Some instalments of the series could be described as an anatomy of the subject: Perfect Skin VI extracts from Kim's selfies the set of corresponding Pantone colours (2016); in Perfect Skin IX, Kim's body shape is unfolded and unwrapped into geometrical drawings that evoke a milliner's patterns. Others explore a variety of formats: for Perfect Skin IV Chatonsky printed the images on blocks of ceramic and in Perfect Skin VII (2017) close up details of a rough dark skin were printed on paper and ceramics. In 2018 Chatonsky exhibited his work in the Diagonale Gallery in Montreal with Dominique Sirois. It featured Perfect Skin in several mediums (photo, video, textiles, ceramics, VR), some on-screen, others in the form of sculptures. Its presentation on Chatonsky's website states that "the artists have realized their project in a spirit of speculation as if all these images could be condensed into one diagram of a single collective and desiring body." ${ }^{3}$ 
Figure 3. The Diagonale exhibition in Montreal, 2018.

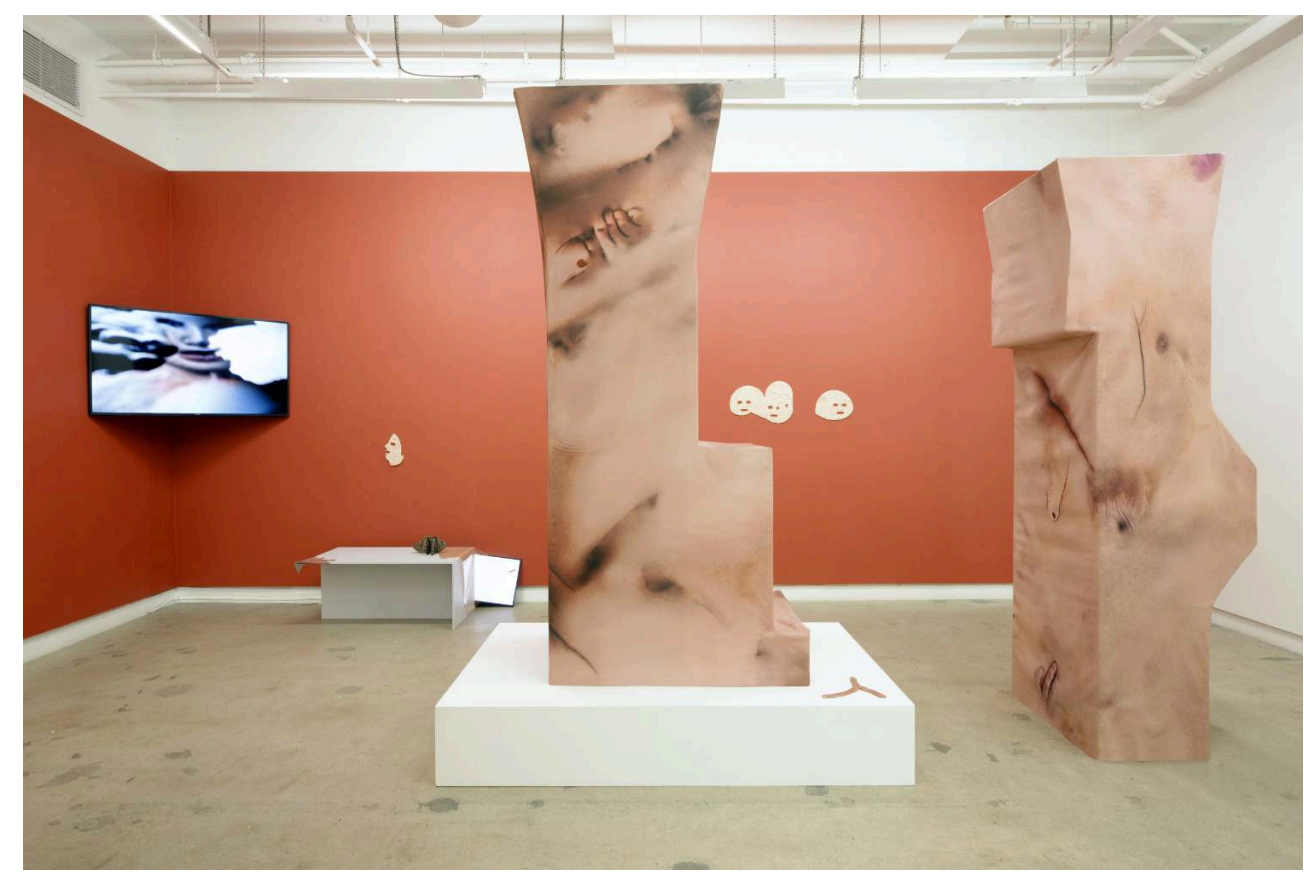

(c) Gregory Chatonsky.

7 Multiplying images while suggesting they are based on a single underlying diagram highlights the tension between proliferation (of online visual content) and originality. However, the distortions introduced by the machine and the serial nature of the work mean that the material used (Kim Kardashian's snapshots) loses its indexicality. Perfect Skin does not create self-portraits, not selfies, nor studies of an individual; it is a declension of variations on a dataset. The artwork does not focus on the real features of the human model, whose presence becomes vestigial, lingering as traces or remains, as a visual ghost haunting the digital image. This erases the self-narrative Kim Kardashian has been producing through social media over the years, as a business woman, a global beauty queen and a role model. Gregory Chatonsky's questioning of the identity and new narratives that emerge from online social media practices appears to shun social considerations to coalesce around the tension between figuration and disfiguration. One should add that the last two instalments of Perfect Skin shift the focus away from celebrity selfies into more dislocation and disfigurement: Chatonsky ran the AI on pictures of cancerous skin cells and enlarged the scales of a pangolin, as a nod to the supposed origins of the pandemic. At face value, the pictures in Perfect Skin relate to the already well-established field of "grotesques" but I would contend their interest lies not in the content, that is the visual markers, but in the process, the exploitation of the digital.

\section{Discretization and generative algorithms}

8 Chatonsky capitalizes on the latest IT technology such as deep learning, neural networks and generative algorithms to foster what he calls AIship, the creative power of artificial intelligence, a word coined on the model of craftsmanship. These techniques rely on a three-step process of collection, discretization and combination: collecting 
data in the form of thousands of pictures, turning these pictures into sets of discrete elements and rearranging them through an algorithm. And to enact those chancebased re-combinations, Chatonsky exploits the possibilities offered by data breakdown, scale issues and genre switching.

Chatonsky commented that "technologies have always interested me, on the one hand, for how they break down and, on the other hand, for how they form a context that exceeds us, in other words, a world. (2015: 2)". He used techniques of pixilation and extraction of data for Perfect Skin VI, in which a frontal photograph of Kim Kardashian is superposed to a range of Pantone colours extracted from the same photograph, in a manner reminiscent of interior design and decoration trend books. One should add that treating digital images as data enables almost limitless breakdowns of the image, according to the variables one wishes to use: colours, shapes, details etc. Discretization and proliferation are two sides of the same technological digital coin.

Figure 4. The pantone breakdown of Kim, Perfect Skin VI, 2016.

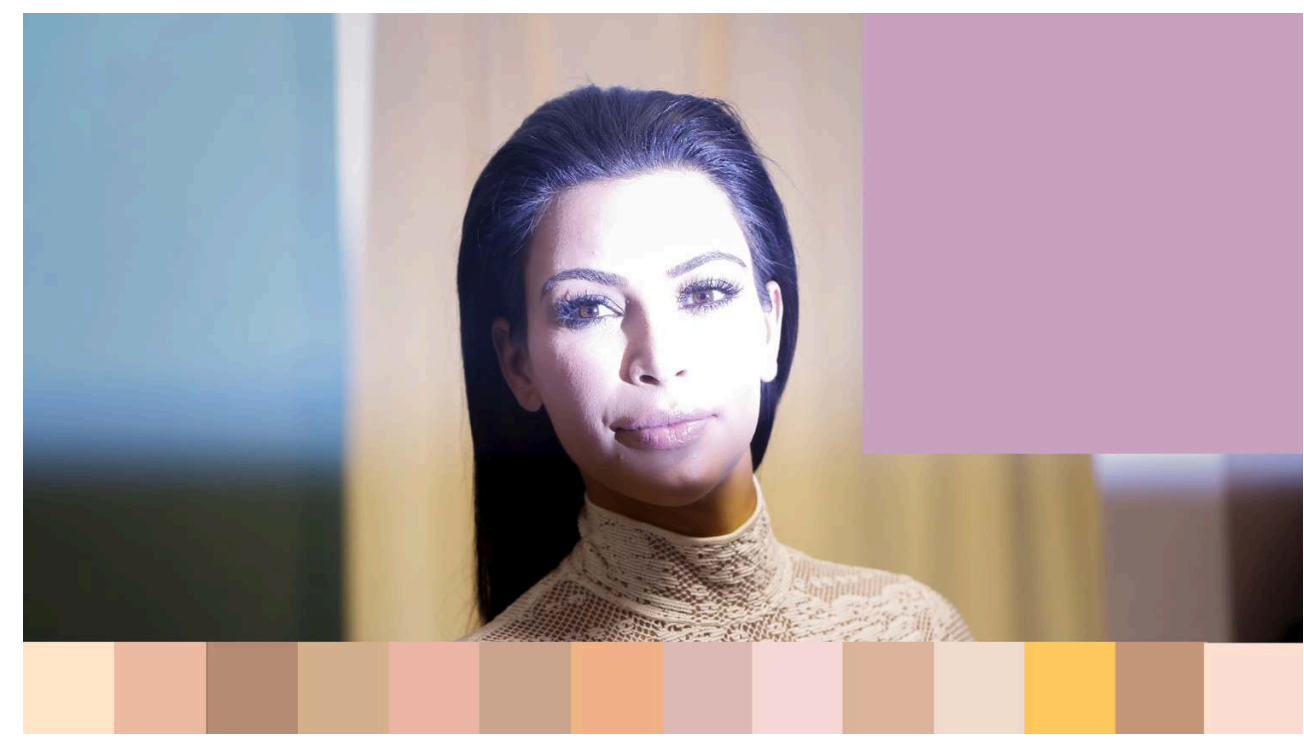

(c) Gregory Chatonsky.

The second digital feature Chatonsky capitalizes on is the management of scale. Kim Kardashian's Instagram account features more than 5000 posts; the hashtag \#kimkardashian yielded 890000 results in July 2021. Our minds cannot grasp this amount of content, our timelines cannot accommodate them. Only computer space, i.e. servers, can house this amount of data and only algorithms and bots can monitor or exploit them. Perfect Skin, which generates a continuous stream of recomposed images of Kim, mirrors the real-life process of continuous selfie posting. Scale is both a matter of volume, of distance to the object (close-ups) and of temporality in Chatonsky's view, who is interested in the sense of urgency and of awe it elicits in the viewers.

La fragmentation des médias déjà existants (ce que certains nomment le big data), joués aléatoirement, produit un tempo que les médias de masse du XXe ignoraient. Elle nous place face à une infinitude, entendez un infini de la finitude, la fêlure même du sujet parce que nous sommes confrontés à quelque chose qui dépasse nos capacités perceptives. $(2017,12)$

11 Data exploitation and the manipulation of digital possibilities are not only a method used to produce Perfect Skin: they are its focal point and the lever Chatonsky used to repurpose selfies. Chatonsky's work may echo Frosh's definition of selfies, "see me 
showing you me" (2015: 1610) and transpose it as "see AI showing you X", with X's status to be defined.

\section{Dis-figuration: Bacon and Chatonsky}

12 Central to his reformatting of selfies is a shift from the visual form of a face to the concept of a figure (the $\mathrm{X}$ aforementioned). In this respect, one could compare Chatonsky's work to that of Francis Bacon, the British painter. Both artists make extensive use of triptychs and polyptychs, themselves embedded in series of paintings or pictures. They also share a form of obsession with a particular sitter: Kim Kardashian for Chatonsky and George Dyer for Bacon. They both revisit the art of the portrait through distortions, blurred lines, twisted perspectives. They also both introduced an element of chance in their method (scratching the surface for Bacon, delegating choice to algorithms for Chatonsky) which opens up the work to a different temporal plane, a form of heterochrony, the "untimely art" (l'intempestif) as commented by Severine Letalleur-Sommer. Finally, they shared an interest in photographic portraits and variations of the same face, as pointed out by Letalleur-Sommer:

On sait également qu'il [Bacon] se servait pour ses portraits de photos d'identité de photomatons où un même format reprend un même visage selon différentes expressions. L'on sait aussi qu'il s'est largement inspiré de clichés de Muybridge sur la décomposition du mouvement, notamment de mouvements de corps difformes qui permettent d'attirer le regard sur un dynamisme atypique. (2017, p.7, \$22)

Distorting the images provokes thus another shift, from the indexicality of the mirror image to intellectual and aesthetic speculation. Bacon and Chatonsky are here further linked by a third party: Deleuze's reflections on what constitutes a Figure and how it emerges from pictorial work, mostly in Deleuze's essay on Bacon's paintings, Logique de la sensation. For him a Figure emerges from the distortion of representation, from its blurring, and is to be distinguished from figurative images: "On part d'une forme figurative, un diagramme intervient pour la brouiller, et il doit en sortir une forme d'une tout autre nature, nommée Figure" (145). Chatonsky repeatedly refers to Deleuze in his texts and the hashtags associated with Perfect Skin; he also confirmed in a private conversation the topicality of the above quotation. The notion of a diagram is key and common to Bacon, Chatonsky and Deleuze, yet in a slightly different sense for each. Bacon focused on the creative process where he introduced random marks to open up possibilities: "les marques [involontaires] sont faites et on considère la chose comme on ferait d'une sorte de diagramme. Et l'on voit à l'intérieur de ce diagramme les possibilités de faits de toutes sortes s'implanter" (Entretien avec David Sylvester 1975, 110-11). Drawing upon Bacon's remarks, Deleuze offers another definition of the diagram, one that focuses on geometrical abstractions and which highlights the specific genius of an artist:

Le diagramme, c'est l'ensemble opératoire des traits et des taches, des lignes et des zones. Par exemple, le diagramme de Van Gogh: c'est l'ensemble des hachures droites et courbes qui soulèvent et abaissent le sol, tordent les arbres et font palpiter et qui prennent une intensité particulière à partir de 1888. (Logique de la sensation 95)

Chatonsky's original contribution to the art of disfigurement and diagram lies in his use of algorithms to break down representations into data and to introduce an element of chance. The generative power of the algorithm is the diagram that disturbs the mimesis and fuels the creativity of the artist. Mimesis is also challenged by the erasure 
of background, the absence of context, which may undermine our assumptions, the ready-made perceptions we carry with us. In keeping with Deleuze's analysis of Bacon's work, setting, scenery, environment are reduced to a minimalistic presence: "le peintre n'a pas à remplir une surface blanche, il aurait plutôt à vider, désencombrer, nettoyer" (83). There is no background in Perfect Skin, contrary to Kardashian's snapshots which are usually tagged for a venue or an event and little background equally in Bacon's triptychs. Didier Ottinger mentioned in his analysis of Bacon's later paintings that they were able to loosen up their mimetic ties ("désarrimer les sujets de ses peintures de l'autobiographie, pour les doter d'une signification plus large"), through two distinct processes : shapeless human forms, hints of mass collective representations (3).

Figuration and disfiguration thus go hand-in-hand. The distortions and deformities introduced by Bacon and Chatonsky will shock their viewers and create a sense of unease. However, the artificiality of these images, their remoteness from realism, create an aesthetic plane where a cognitive shift may happen and enable us to move beyond feelings of awe and disgust. The body of the sitters are first reduced to a set of "organs without bodies" (one of the categories used by Chatonsky to structure his corpus of work on his website) and then rearranged in another composition that may match the definition of a "body without organs" offered by Deleuze \& Guattari as "une surface glissante, opaque et tendre, fluide, amorphe, indifférenciée" (Anti-Oedipe, 15). The Figure in Deleuze's analysis emerges from figurative data and via its deconstruction as "the improbable", a composition that coincides with an event: "extraire la Figure improbable de l'ensemble des probabibilités figuratives" (Logique de la sensation 90). In Chatonsky's work, one may argue that the Figure, that "opaque and slippery surface", emerges from the flow of computer-generated images rather than from paintings on canvases. Always keen to test digital possibilities, and with a certain relish for the reversal of functions, Chatonsky used technology based on probabilistic computation to create the improbable. Following Simondon's intuition that technology produces not only artefacts but how we inhabit the world and the meanings we confer upon it, Chatonsky's creative work embeds an exploration of technology and its ramifications.

\section{The challenges of legitimation}

However, some differences between Bacon's work and Chatonsky's point to a different configuration of their artistic, social and aesthetic milieus, where the choice of format and the reception of the work are closely linked. Bacon embraced the career of a painter whose production fell within well-established pictorial categories and genres, notably portraits and triptychs. His work was displayed in galleries, art fairs and museums. The format of his paintings, i.e. their large dimensions since each section of the triptychs usually stands at $198 \times 147 \mathrm{~cm}$, pre-empts their destination: large public spaces where contemporary art is displayed.

Chatonsky on the contrary presents himself as a Web artist with a background in philosophy: this field, though by now established and recognized within the artistic profession, is not well known by the general public. Many would not classify it as fine arts: hence there arises an issue of legitimacy and the need for strategies of legitimation. One should also add that by repurposing Kim Kardashian selfies, Chatonsky tackled a controversial emerging genre, one that triggered many public 
condemnations on moral grounds for narcissism (discussed by Seidman 2015 and Wagner 2015), or frivolity (Abidin 2016). Selfies are also decried for aesthetic reasons: Koestler denounced the tastelessness of selfies in Vice (2014) and Jones described them as "idiotic travesty" in The Guardian (2015). The cover of Kardashian's book, Selfish, though produced by a publishing house specializing in coffee-table books, focused on a frontal picture of her breasts, with sparse artistic licence. One possible strategy of legitimation is based on the reception of one's work, notably through the choice of venues: Chatonsky alternates between the viewing space of websites, which are also the prime venue for selfies and enable unlimited private practices of navigation, and the viewing space of the gallery, which gives limited access to a public display. Perfect Skin strides across those two milieus, social media metrics and art gallery criticism. This tension between two modes of legitimation is one shared by Kardashian herself. Indeed, the brand name of her publisher, Rizzoli, conferred upon Kardashian's selfies some cultural distinction, at least from an institutional point of view; on the other hand, by using Kardashian's snapshots, Chatonsky ${ }^{4}$ could hope to benefit from the considerable public exposure of the celebrity, and use the buzz to divest some attention to his work, building upon the outrage factor, sexual connotations and technological hype.

The second strategy of legitimation focuses on the literary and philosophical intertext Chatonsky explicitly associates with this visual work. The 2007 prototype of Perfect Skin is framed by Céline's injunction: "In writing, you need to put your skin on the table" $(1959)^{5}$. The 2018 exhibition quotes Merleau-Ponty in the Phenomenology of the Perception $(1945)^{6}$ : "a living body seen from too close, and lacking any background against which it could stand out, is no longer a living body, but rather a material mass as strange as the lunar landscape." Chatonsky's Instagram account juxtaposes the label of "artist" with a set of four notions (Consummation Learning Extinction Resurrection) and the About section of his Facebook page lists "artist, research fellow and adjunct professor": his self-branding is thus systematically dual, academic and artist.

The third strategy of legitimation uses a shift in pictorial genres, from the portrait to the landscape. When reformatting Kim's selfies into serrated superimposed sections of her profile, Chatonsky aims at creating the strange "lunar landscapes" evoked by Merleau-Ponty. He further comments on his fascination for landscapes as the touchstone of digital world-making:

The notion of the landscape takes on a new importance: the artist appropriates media and rearranges them so as to produce something not contained in the original images. Here once again, it is a matter of re-appropriating through the artistic work that which is imposed on us, of re-singularizing that which has no singularity - the ordinary, the insignificant, the zero-level of sensation - by diving even deeper into the web to test its transcendental limit, rather than by contesting its anonymity. (2015: 31) 
Figure 5. Landscape portrait of Kim, Perfect Skin II, 2015.

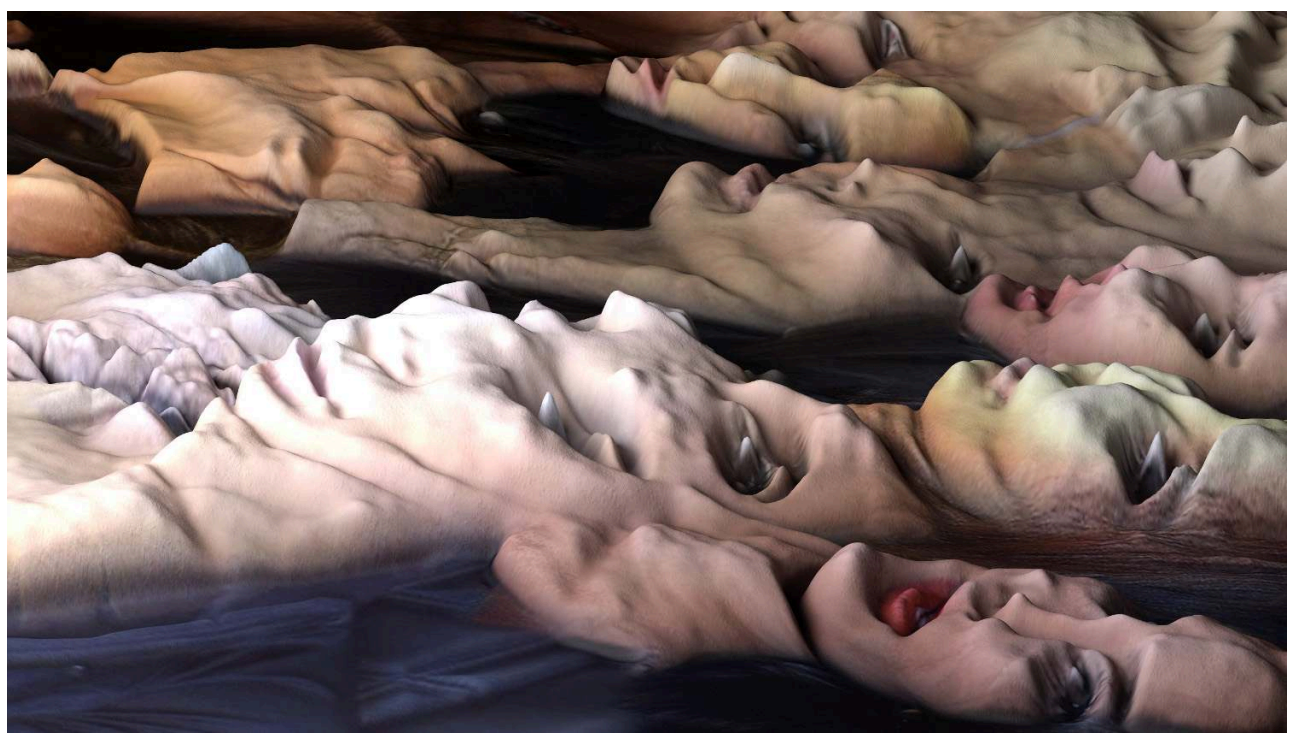

(c) Gregory Chatonsky.

This genre-switching from portrait to landscape also legally protects Chatonsky's appropriation of Kim's images which under intellectual property law would belong either to her or to Instagram. The switch can operate precisely because these selfies are treated as visual data instead of portraits, because they do not represent an individual person but constitute her "data double" (Haggerty and Ericson, 606). Moreover, the landscapes Chatonsky generates could be understood both literally and as a metacomment since the media hype surrounding Kardashian is part and parcel of our collective mental landscape. Perfect Skin is not just about producing new artistic creations but also about commenting on our digital condition, engaging with the current politics of the self.

\section{Politics of the self in the digital economy}

21 The choice of Kim Kardashian as the object of artistic re-appropriation is itself significant. Whereas Bacon's triptychs derive much of their urgency and their poignancy from his personal relation to George Dyer, Chatonsky has no connexion to Kim Kardashian other than as an anonymous follower of her social media accounts. The project is not about her person but about celebrity posting frenzy. It could technically have been any other celebrity and ended up being her because of her extreme media exposure. From the very beginning of her career, Kim Kardashian has exploited her private life and her body as capitalistic means of production, yielding considerable financial profits. Kim Kardashian's career as a professional celebrity started in her family's reality TV show launched in 2007 but took another dimension through her personal accounts on Tumblr and Instagram. As of the $2 \mathrm{~d}$ of July 2021, she has uploaded 5572 posts on her Instagram account, viewed by 232 million followers, to which one should add the numerous websites and social media accounts dedicated to her but run by her fans. The exposure of her daily life enabled her to achieve worldwide fame and helped her launch several businesses selling beauty products and bodysuits. 
2007 release of a sex tape, or the coincidence of her wedding ceremony with the launch of a perfume, are just a few examples of the publicity stunts she excels at. When nude photographs of her were published in Paper in 2014, a Time magazine writer commented that, unlike previous celebrities' nudes that represented the women's rebellion against repressed society, Kardashian's exhibition was :

just provocation and bluster, repeated images that seem to offer us some sort of truth or insight but are just self-serving. Kim Kardashian's butt is the biological equivalent of click-bait. We can't help but pay attention to it, but we're always upset by the lack of substance. (Moyner 2014)

Although the Paper photograph quoted Jean-Paul Goude's work in Jungle Fever and sparked a discussion about the representation of black females in the media (Butler 2014), many readers and most Instagram followers would not have been able to recognize the reference. The publication of this belfie (selfie of a butt) triggered 15.9 million views in one day on Paper's website, compared with 25,000 views on an average day (Grossman 2014). And it further added to Kim's considerable wealth estimated at $\$ 900$ million in 2020 (Berg 2020). The scale of exposure is what matters here and Kardashian's self-branding is the epitome of current trends in the digital economy. In this instance, one could truly talk about an economy of the self, where a limited set of artefacts yields a maximum profit. It also feeds into a global "economy of attention" (Citton 2014) where the circulation of information, flow and buzz, are the true source of wealth and can be dissociated from the actual production of any goods. One might say that it's not the quality of the images themselves that matters but the constant flow of posting that feeds the buzz.

The title on the cover of that famous edition of Paper, and a possible caption for Kim's nude photograph was "Break the Internet". Whether it was intended as a comment or an imperative is not clear. What is clear however is that Kardashian's status as a celebrity would not exist without the Internet, and the Internet thrives on the likes of her.

Chatonsky, in his theoretical essay "Esthétique du flux", reflects upon the ubiquity of the notion of flow in our societies:

Cette brève traversée nous a permis de comprendre que la question des flux ne concernait pas seulement le réseau Internet, mais d'autres flux, celui de notre conscience, de notre perception, de l'économie, des médias de masse. Internet est sans doute aujourd'hui la forme privilégiée du réseau, son symptôme le plus intense, mais n'est pas exclusif d'autres approches. On ne saurait plus séparer l'esthétique des technologies de l'esthétique quotidienne, parce que la première est inextricablement entrelacée à la seconde (2007, 98).

Chatonsky, whose early work was focused on the notion of glitch, likes to point out that art can divert the flow: "suspendre ou détourner la notion même de finalité qui est la forme fondamentale du flux technique, de rendre inutilisable les technologies en en modifiant l'horizon d'attente" $(2007,89)$. By repurposing Kim's selfies and extracting them from their social media context, he subverts their immediate mercantile finality whilst spinning them into a different kind of flow, that of artistic content. This might be one of the limits of his approach. The value of his images still lies in their accessibility, in the fact they are shared and circulated online and offline; obviously, authors and artists need buzz and visibility to make a living and continue creating. Chatonsky thematized this hyperproduction as a critique of industrial production : 
How is our desire transformed by data on the network? How to free objects from the repetition of the identical? What is the account of this excess of production? How to accelerate production beyond capitalism? to the stereotypes of global manicured beauty, still create a set of pictures that bear a strong resemblance to each other, and re-enact the repetition of the identical. A more interesting contribution of Perfect Skin to a criticism of contemporary societies might be the fact that it abandons the practice of representation as mimesis to enter a regime of affect, as defined by Brian Massumi, who draws upon the definition given by Spinoza of affect as "the power to affect and be affected" (ix). Affect is to be distinguished from emotion and should not be reduced to its psychological aspects. Presented as a processual concept, affect happens in the relation between an individual, an event and their complex milieu: "one always affects and is affected in encounters; which is to say, through events. To begin affectively in change is to begin in relation, and to begin in relation is to begin in the event." (ix). Eckel's definition of the selfie as both an image and a social practice also suggests that selfies are best seen as a micro-social event and that their meaning lies as much in the event of their posting as in the specifics of the image. Chatonsky's reworking of those selfies literally affects both their visual form and their social context. He subverts the beauty canon and the social theatricals involved in the presentation of self (Goffman 1959); he uses the computer's ability to produce an infinite number of recomposed images to provide a unique viewing experience, a performance (or artistic event) through which we are confronted to improbable and disturbing combinations (a personal event for the viewer) and that may be read as a comment on our digitally-driven societies (a collective event).

\section{Conclusion}

The second decade of the $21^{\text {st }}$ century witnessed a coincidence between the development of many IT technologies (smartphones, deep learning, databases), the growing prevalence of an economy of attention and the social practice of selfies, identified as a form of conversation as much as an aesthetic item (Eckel 2018). Perfect Skin as a series exposes the obsession of our societies with the vortex of spin, buzz and flow; it showcases our reliance on computer-generated and computer-circulated content and our fascination for self-exposure. Chatonsky's decision to appropriate a dataset of selfies by a global celebrity and reprocess them algorithmically thus feeds on two of our society's most prurient obsessions. But recasting those selfies into another (visually uncomfortable) format enables Chatonsky to shift the focus away from their indexicality. Following Peirce's distinctions, one might argue he created in Perfect Skin a set of indices, signs that are just the trace of something. Traces of Kim Kardashian's celebrity status, traces of the media frenzy for self-exposure, traces of algorithmic processing of images, traces of multiple artistic references and a quest for legitimacy. In so doing, willingly or not, he underlined some of the ambiguities of our times. Is legitimacy to be equated with the level of buzz and a state of heightened attention, rekindled by each instalment of a series (Kardashian's snapshots, Chatonsky's works)? Should the focus be on the content (the images) or the process of repurposing, meming and sharing? Instead of equating the artist with the author, should we get used to various layers of authoring? Kim Kardashian for the snapshot, social media for their 
display, Chatonsky for designing the algorithm and choosing the format in which the results are displayed...

The title of his series, Perfect Skin, exemplifies the equivocal, elastic distance Chatonsky navigates between his material and his work: it can be read as an ironical comment on the superficiality and narcissism of selfies, or an acknowledgement of the importance of make-up as self-design. The shift in format AI enables him to perform corresponds to a shift away from both mimetic expectations and online social practices. Away but not entirely: therein lies both the originality and the limitations of his work.

\section{BIBLIOGRAPHY}

\section{Works cited}

ABIDIN, Crystal. “Aren't These Just Young, Rich Women Doing Vain Things Online? Influencer Selfies as Subversive Frivolity." Social Media+Society 2 (2016): 1-17.

BACON, Francis. L'art de l'impossible. Entretien avec David Sylvester. Genève: Skira, 1975.

BERG, Madeline. "Kim Kardashian West is worth $\$ 900$ million after agreeing to sell a stake in her cosmetics firm to Coty." Forbes magazine, 29 June 2020 (accessed July 15, 2021) https:// www.forbes.com/sites/maddieberg/2020/06/29/kim-kardashian-is-selling-a-stake-in-hercosmetics-firm-to-coty-for-200-million/?sh=6b7a308d5150

BUTLER, Bethanie. “Yes, those Kim Kardashian's photos are about race.” The Washington Post, 21 November 2014. https://www.washingtonpost.com/blogs/she-the-people/wp/2014/11/21/yesthose-kim-kardashian-photos-are-about-race/ (accessed July 15, 2021)

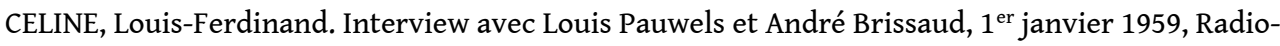
Télévision Française. https://www.ina.fr/ina-eclaire-actu/video/cpf86632261/celine (accessed October 18, 2021)

CHATONSKY, Gregory. « Esthétique du flux ». Rue Descartes 55 (2007): 86-99.

CHATONSKY, Gregory. “Post All Internet. Three Figures.” ETC MEDIA 106 (2015): 29-32.

CHATONSKY, Gregory, “24 Mai 201522 H 34. ” ETC MEDIA 110 (2017), 12-15.

CHATONSKY, Gregory. http://chatonsky.net/_(accessed July 15, 2021)

CITTON, Yves. L'Economie de l'attention, nouvel horizon du capitalisme ? Paris: Editions de la Découverte, 2014.

DELEUZE, Gilles. 1981. Francis Bacon Logique de la sensation. Paris: Seuil, 2002.

DELEUZE, Gilles and Félix GUATTARI. Anti-Edipe. Paris: Editions de Minuit, 1972.

ECKEL, Julia, RUCHATZ Jens and Sabine WIRTH, eds, Exploring the Selfie. Historical, Theoretical, and Analytical Approaches to Digital Photography. London: Palgrave-Macmillan, 2018. 
ECKEL, Julia "Selfies and Authorship: On the Displayed Authorship and the Author Function of the Selfie", in ECKEL, Julia, RUCHATZ Jens and Sabine WIRTH, eds, Exploring the Selfie. Historical, Theoretical, and Analytical Approaches to Digital Photography. London: Palgrave-Macmillan, 2018: 160-198.

FROSH, Paul. "The Gestural Image: The Selfie, Photography Theory, and Kinaesthetic Sociability", International Journal of Communication 9 (2015): 1607-1628.

GOFFMAN, Erving. The Presentation of Self in Everyday Life. New York: Doubleday, 1959.

GROSSMAN, Samantha. “Top 10 Things That Broke the Internet”, December 2, 2014. Time. https:// time.com/3587943/things-that-broke-the-internet/ (accessed July 15, 2021)

GROYS, Boris. Going Public (e-flux journal). Berlin: Sternberg Press, 2010.

HAGGERTY, Kevin D., and Richard V. ERICSON. 'The Surveillant Assemblage.' In The British Journal of Sociology 51 (4), 2000: 605-22.

KARDASHIAN WEST, Kim. Selfish. New York, NY: Universe/Rizzoli, 2015.

LETALLEUR-SOMMER, Séverine. «L'un et le multiple ou la question de l'intempestivité dans les triptyques de Francis Bacon », Polysèmes 17 (2017). http://journals.openedition.org/polysemes/ 1811 (accessed July 15, 2021)

MASSUMI, Brian. Politics of Affect. Cambridge: Polity Press, 2015.

MERLEAU-PONTY, Maurice, Phénoménologie de la perception, Paris: Gallimard, 1945.

MOYLAN, Brian. “Kim Kardashian's Butt is an Empty Promise”. November 12, 2014. Time. Time Inc. https://time.com/3581618/kim-kardashian-butt-paper-magazine-empty-promise/_accessed July 15,2021$)$

OTTINGER, Didier, dir. Bacon en toutes lettres. Paris: Centre Pompidou, 2019.

RETTBERG, Jill Walker. Seeing Ourselves through Technology: How We Use Selfies, Blogs and Wearable Devices to See and Shape Ourselves. New York, NY: Palgrave Macmillan, 2014.

SEIDMAN, Gwendolyn. What Is the Real Link Between Selfies and Narcissism? Psychology Today (August 6, 2015). https://www.psychologytoday.com/blog/close-encounters/201508/what-isthe-real-link-between-selfies-and-narcissism_(accessed July 15, 2021)

TIFENTALE, Alise. “The Networked Camera at Work: Why Every Self-Portrait Is Not a Selfie, but Every Selfie Is a Photograph”. In Riga Photography Biennial 2016, ed. Santa Mičule, 74-83.

WAGNER, Eric T. Selfie Society: Narcissism and the Celebration of Mediocrity. Montreal: Pressbooks, 2015.

\section{NOTES}

1. http://enposs.eu/events/conference-figurations-persons-in-out-of-data-conference/

2. http://chatonsky.net/perfect-skin-prototype/

3. http://chatonsky.net/expo-perfectskin/ consulté le 15 décembre 2020.

4. As of July 2021, Chatonsky's Instagram account has 2438 followers and a query on Google for his exact name yields 11800 results. The query for « Kim Kardashian » on the same date (July 2, 2021) yields 231 million results and she has 232 million followers on Instagram. 
5. «Alors j'ai mis ma peau sur la table, parce que, n'oubliez pas une chose, c'est que la grande inspiratrice, c'est la mort. Si vous ne mettez pas votre peau sur la table, vous n'avez rien. » Interview avec Louis Pauwels et André Brissaud, $1^{\mathrm{er}}$ janvier 1959.

6. " un corps vivant, vu de trop près, et sans aucun fond sur lequel il se détache, n'est plus un corps vivant, mais une masse matérielle aussi étrange que les paysages lunaires ", p. 348-349.

\section{7. http://chatonsky.net/category/corpus/hyperproduction/}

\section{ABSTRACTS}

In the series Perfect Skin launched in 2015, Gregory Chatonsky, a French Canadian artist, ran an AI programme on the more than 5000 Tumblr and Instagram selfies posted by Kim Kardashian, to create distorted and serial representations of the celebrity which were then reproduced through a series of media: photo, video, textiles, ceramics, VR. Chatonsky challenges the genre of the selfie on several accounts. He highlights issues such as scale and exposure within the infoglut. Using algorithms also enables him to trigger cognitive and artistic shifts: from the visual arts to mathematics, from representation to data, from creative control to chance, from recognition to perceptual aporia, from social media to the gallery. These distorted and serialised images, "organes sans corps" to take up Deleuze's famous concept, may pertain to a regime of meaning based on affect, as defined by Brian Massoumi, rather than on mimesis.

Dans la série Perfect Skin lancée en 2015, l'artiste franco-canadien Gregory Chatonsky a utilisé un algorithme d'intelligence artificielle sur un ensemble de plus de 5000 selfies postés par Kim Kardashian sur Tumblr, pour créer une série d'images déformées de la célébrité qui ont ensuite été reproduites sur différent supports : photo, vidéo, textiles, céramique, réalité virtuelle. Chatonsky remet en question le genre du selfie à plusieurs égards. Il pose la question de l'échelle des images et de leur exposition médiatique en ligne. L'utilisation d'algorithmes lui permet également d'opérer plusieurs renversements cognitifs et artistiques : des arts visuels aux mathématiques, de la représentation aux données, du contrôle créatif au hasard, de la reconnaissance à l'aporie perceptive, de l'espace des réseaux sociaux à celui de la galerie. Ces images déformées et sérialisées, “organes sans corps" pour reprendre le célèbre concept de Deleuze, pourraient relever d'un régime de sens basé sur l'affect, tel que défini par Brian Massoumi, plutôt que de la mimésis.

\section{INDEX}

Mots-clés: selfie, portrait, données, algorithmes, réseaux sociaux, affect, représentation, distortion, célébrité, exposition de soi

Keywords: selfie, portrait, data, algorithm, social media, affect, representation, distortion, celebrity, exposure 


\section{AUTHOR}

\section{CLAIRE LARSONNEUR}

Université Paris 8, TransCrit

Claire Larsonneur est maître de conférences hors classe à l'Université Paris 8, dans l'équipe TransCrit. Sa recherche porte sur la traduction, la littérature britannique contemporaine et les humanités numériques. L'étude des œuvres littéraires et artistiques contemporaines s'articule à une recherche plus théorique sur les variations de la notion du sujet à l'heure numérique, menée au travers du projet Labex ARTs H2H « Le Sujet digital », du colloque de Cerisy « Posthumains et subjectivités numériques » (2016) et du numéro d'Angles « Digital Subjectivities » (2018). Elle contribue à l'animation du séminaire EPHN, Epistémologies et pratiques des humanités numériques, à Paris 8. Publications récentes : When Translation Goes Digital (co-direction avec Renée Desjardins et Philippe Lacour), Palgrave-Macmillan, 2020 ;Subjectivités numériques et posthumain (co-direction avec S. Bauer, L. Machinal, A. Regnauld), Presses Universitaires de Rennes, 2020 ; Le Sujet digital (co-dir. avec P. Cassou-Noguès, A. Regnauld et S. Touiza), Presses du réel, 2015 ; "Travailler sur des objets numériques hyper-contemporains: de nouvelles pratiques", ILCEA, 2020 ; "Glow or the hallucinated city", Polysèmes 22, December 2019. 